DOI 10.34883/PI.2021.7.2.004

UDC 616-006.6:611-018

Andriiaka A.

Shupyk National Healthcare University of Ukraine, Kyiv, Ukraine

Андрияка А.A.

Национальный университет охраны здоровья Украины имени П.Л. Шупика, Киев, Украина

\title{
Results of the Study of the Plasma Level of Free Heparin in Patients with Colorectal Cancer, the Course of Which was Complicated by Anemia of Malignant Neoplasm
}

\author{
Результаты исследования содержания \\ свободного гепарина в плазме крови пациентов \\ с колоректальным раком, течение которого осложнялось \\ анемией злокачественного новообразования
}

\begin{abstract}
Colorectal cancer is an extremely urgent issue in modern medicine. This disease is often complicated by anemia, which has specific pathogenetic mechanisms of development and forms a mutual burden syndrome of diseases in cancer patients. The anemic syndrome is accompanied by the development of tissue hypoxia, which in turn activates the processes of oxidative stress and leads to increased release of biologically active compounds, in particular, heparin. We have examined 153 patients with colorectal cancer without anemia, 75 patients with colorectal cancer complicated by malignant tumor anemia, and 53 patients with iron deficiency anemia. The control group consisted of 50 healthy primary donors. The content of free heparin fractions in plasma were determined with the method proposed by Mykhailychenko B., Vydyborets S. (2000). The patients with iron deficiency anemia and malignant tumor anemia had a significant increase of free heparin in plasma, if compared with the control group and the group of patients with colorectal cancer without anemia. Free heparin in plasma was increasing together with the severity of anemia. In the article, there is discussed the feasibility of using the content of free heparin in plasma, as an option, to assess the state of compensation of the secondary metabolic disorders in iron deficiency anemia and malignant tumor anemia during treatment and its possible differential diagnostic value.
\end{abstract}

Keywords: anemic syndrome, hypoxia, free heparin, blood plasma, malignant tumor anemia, iron deficiency anemia, colorectal cancer.

Резюме

Колоректальный рак является чрезвычайно актуальной проблемой современной медицины. Часто заболевание осложняется анемией, которая имеет специфические патогенетические механизмы развития и формирует синдром взаимного отягощения заболеваний у онкологических пациентов. Известно, что анемический синдром сопровождается развитием гипоксии 
тканей, которая в свою очередь активизирует процессы оксидативного стресса и приводит к усилению высвобождения биологически активных соединений, в частности гепарина. Обследовано 153 пациента с колоректальным раком без анемии, 75 пациентов с колоректальным раком, течение которого осложнялось развитием анемии злокачественного новообразования, и 53 пациента с железодефицитной анемией. Контрольную группу составили 50 первичных доноров. Содержание свободного гепарина в плазме крови определяли методом Михайличенко Б.В., Выдыборца С.В. (2000). Установлено, что у пациентов с железодефицитной анемией и анемией злокачественного новообразования имеет место достоверное увеличение показателя содержания свободного гепарина в плазме крови, по сравнению с контрольной группой и группой пациентов с колоректальным раком без анемии. Повышение показателя содержания свободного гепарина наблюдали по мере нарастания тяжести анемии. В статье обсуждаются возможности использования показателя содержания свободного гепарина в плазме крови как дополнительного критерия для оценки состояния компенсации вторичных метаболических нарушений при железодефицитной анемии и анемии злокачественного новообразования в процессе лечения и возможное его дифференциально-диагностическое значение.

Ключевые слова: анемический синдром, гипоксия, свободный гепарин, плазма крови, анемия злокачественного новообразования, железодефицитная анемия, колоректальный рак.

\section{- INTRODUCTION}

The incidence of rectal cancer in Europe is 35\% of all cases of colorectal cancer (CRC), that is, 15-25 patients per 100 thousand population per year [1]. Mortality caused by this pathology is $4-10$ cases per 100 thousand per year. Colorectal cancer occupies the fourth place in the structure of general cancer incidence among women and fifth among men in Ukraine [2]. CRC in the structure of female cancer mortality ranks second and fourth in the structure of male mortality. Over the past 30 years, the CRC incidence has increased by 4 times. The excess incidence is observed all over the world the most intensively in the countries of Western and Eastern Europe and North America (Canada, Great Britain, Austria, USA, Czech Republic, Poland, Ukraine) [1, 3].

In Ukraine in 2018 the ratio was 25.6 per 100 thousand population (crude ratio), 13.6 (standardized ratio, world standard). It is approximately the same for men and women (26.7 and 24.7 per 100 thousand population, respectively); and the mortality rate was 11.8 per 100 thousand population. CRC incidence and mortality rates are quite high compared to the world rates (incidence is 10.6, and mortality is 6.8 per 100 thousand population). An increase in the incidence rate by $2.2 \%$ per year has been determined. The incidence rate is higher in the urban population than in the rural population. The highest incidence is observed at the age of 70-79 years; the greatest risk of developing CRC is in persons aged 60 years and older (it is higher in men (3.2\%) than in women $(2 \%)[2,4]$.

In most cases, CRC (almost $90 \%$ of cases) is adenocarcinoma of different degrees of differentiation, consisting of the glandular epithelial cells of the segmented intestine and rectum. In addition, but much less frequently, squamous cell carcinomas, signet ring cell carcinomas and undifferentiated carcinomas may occur. Etiology CRC occurs sporadically in about $60-65 \%$ of all cases (i.e., it occurs in individuals without a family history of CRC or in the presence of hereditary genetic mutations which increase the risk of CRC) 
due to acquired somatic and epigenetic aberrations. Approximately $23 \%$ of CRC cases have a family history and no genetic syndromes. Only less than $5 \%$ are hereditary cancer syndromes which include hereditary non-polyposis colorectal cancer (HNPCC, Lynch syndrome) or familial adenomatous polyposis (FAP) caused by mutations in rare but high-penetrant genes (MLH1 and APC); but even in such cases, it is impossible to completely ignore the environmental factors.

The relationship between the CRC development and the patient's nutritional habits has been noted. A diet with a predominant content of proteins and fats (the so-called Western pattern diet) contributes to the occurrence of this disease. Protein metabolic products (tryptophan) are believed to be carcinogenic. Fatty foods increase the level of fatty acids, which, under the influence of intestinal microflora, especially anaerobic microbes, form tumour promoters (such as azoreductases, etc.). Bile acids and modified bile pigments have a certain carcinogenic effect, as well. A carcinogenic effect has been noted in impurities and additives which are used as industrial food preservatives.

The duration of contact of carcinogenic agents with the intestinal epithelium is of great importance; it depends on the rate of intestinal passage. This is why a diet high in fibre which speeds up passage reduces the risk of CRC development.

Some foods contain natural substances with carcinogenic properties flavonoids, coffee, beer, alcohol (acetaldehyde). Smoking significantly increases the risk of this disease.

There is an increased risk of CRC in the presence of non-neoplastic inflammatory diseases of the segmented intestine and rectum, such as ulcerative colitis (in $2.5-12.5 \%$ of new cases), Crohn's disease, inflammatory sigmoiditis, typhlitis, proctitis.

Low physical activity is especially identified as a risk factor for the CRC development.

Overweight is an established risk factor for CRC (more for the segmented intestine than for the rectum) as confirmed by epidemiological studies. The two most commonly used indicators of obesity are body mass index (BMI) and waist circumference (WC). There is evidence that WC is a stronger predictive risk factor for the CRC development. An increase in WC by $10 \mathrm{~cm}$ increases the risk of CRC by about $4 \%$.

Fatty tissue is divided into two sections isolated from each other: visceral adipose tissue (VAT) and subcutaneous adipose tissue (SAT). Compared to subcutaneous adipose tissue, visceral adipose tissue synthesizes more pro-inflammatory adipokines (TNF) and less adiponectin (insulin-sensitizing hormone), and is more strongly infiltrated by immune cells (such as macrophages).

This leads to the development of mild chronic systemic inflammation and insulin resistance. Insulin resistance and, as a consequence, hyperinsulinemia lead to an increase in the amount of free insulin-like growth factor (IGF1), which suggests that this pathway contributes to colorectal carcinogenesis through cell proliferation and decreased apoptosis.

The symptoms of CRC are very diverse and primarily depend on the location of the tumour (different parts of the segmented intestine, rectum and anal canal) and the anatomical growth pattern (exophytic or endophytic). 
The main manifestations of tumours of the segmented intestine and rectum are: pain, anaemia, dyspeptic symptoms, symptoms of the inflammatory process, pathological impurities in the faeces, bowel disorders (constipation or diarrhea, or their frequent changes), the presence of a palpable tumour in the abdomen.

The main and most informative method for the examination and detection of CRC is colonoscopy with a single-stage tumour biopsy. The world recommendations are to conduct fibrocolonoscopy for patients aged 50 years on an annual basis. A faecal occult blood test is preferred but not the most informative screening method.

Once the fact of a tumour of the segmented intestine or rectum is established, it is recommended to perform computed tomography in order to determine the size of the tumour and its behaviour with the surrounding tissues and organs. Also, computed tomography helps to determine the presence or absence of distant metastases, which affects the choice of treatment method (surgery, chemotherapy or radiation therapy) $[5,6]$.

In clinical practice, special attention has recently been paid to the study of physiologically active substances under various conditions. First of all, this is due to their significant biological activity, influence on the occurrence, development and course of biochemical changes in the body. New data on the role of the physiologically active substance, heparin (HPN), in the regulation of metabolism have also accumulated. As the analysis of the scientific literature shows, the HPN activity is manifested not only in the regulation of blood coagulation processes $[7,8]$. This compound is actively involved in control over the processes of angiogenesis and immune reactions; it causes lipolytic and hypoglycemic effects; it has anti-inflammatory, antibacterial and antiviral activity. It is becoming more and more obvious that when using HPN in clinical practice to regulate changes in the hemostatic system, it is necessary to take into account its non-hemostatic effects, since they may turn out to be significant in a number of situations. In the sources available to us, given the publications of recent years, we have not identified fundamental data on the role of HPN, in particular, in cases of colorectal cancer, which prompted us to this work.

\section{- THE OBJECTIVE OF THE WORK}

Is to systematise and generalise data on the role of HPN as a physiologically active substance in metabolic processes in CRC in order to determine promising areas of scientific research and to study changes in the plasma level of its free fraction of heparin in healthy subjects, in patients with iron deficiency anaemia (IDA) and anaemia in malignant neoplasm (AMN) in colorectal cancer to identify possible specific changes and use the value of its level in clinical and differential diagnostic practice.

\section{MATERIALS AND METHODS}

As the study material blood of 110 patients ( 58 men and 52 women) was taken. Among them 53 patients ( 31 women and 22 men) with IDA were examined, they formed the first (I) observation group and 57 patients ( 36 men and 21 women) with colorectal cancer, where the course of the underlying disease was burdened by malignant anemia second (II) observation group. 
The age of the patients under the survey is from 22 to 69 years. All patients were examined before any treatment was prescribed.

The diagnosis of IDA was verified based on a typical clinical picture (signs of anemic hypoxia and sideropenic syndrome), typical hematologic picture of peripheral blood and indicators of iron metabolism.

The severity of anemia was defined according to the criteria proposed by the National Cancer Institute (USA) as follows: mild hemoglobin $(\mathrm{Hb})$ from 10 to $12 \mathrm{~g} / \mathrm{dL}$, moderate $\mathrm{Hb}$ from 8 to $10 \mathrm{~g} / \mathrm{dL}$; severe $\mathrm{Hb}$ from $6.5 \mathrm{~g} / \mathrm{dL}$ to $8 \mathrm{~g} / \mathrm{dl}$, life-threatening $\mathrm{Hb}$ below $6.5 \mathrm{~g} / \mathrm{dL}$. Among the patients with IDA, 19 were diagnosed with a mild type, 15 with a moderate, 11 with severe, and 8 with a life-threatening one. Among the patients with malignant anemia 29 were diagnosed with a mild type, 12 with moderate, 10 with severe, and 6 with life-threatening.

The study was conducted in compliance with the main provisions of the Council of Europe Convention on Human Rights and Biomedicine, Declaration of Helsinki Ethical Principles for Medical Research and (1964, with further additions, including 2000 version) and the Ministry of Health of Ukraine Order No. 690 dated September 23, 2009. All patients admitted to the hospital were examined with the use of clinical, laboratory, instrumental and special research methods, and were consulted by specialists of related specialties, if necessary. The examination and treatment of patients were performed in accordance with the World Medical Association Declaration of Helsinki (Seoul, 2008), and the relevant orders of the Ministry of Health of Ukraine (No. 281 from 01.11. 2000, No. 355 from 25.09.2002, No. 356 from 22.05.2009 in revision of the Ministry of Health of Ukraine Order No. 574 of 5 August 2009, No. 1118 of 21 December 2012).

The control group consisted of 50 healthy primary donors who had no history of cancer or chronic inflammatory disease. All donors were examined at the State Institution "Blood Transfusion Station of the Southwestern Railway" following the requirements of the "Procedure of medical examination of blood donors and (or) its components", approved by the Order of the Ministry of Health of Ukraine dated 01.08.2005 under No. 385 "On infectious safety of donor blood and its components".

Patients with colorectal cancer were conducted with a thorough histological examination of the drugs, taking into account the nature of the tumor margins with the surrounding tissues, the severity of infiltration, the presence of tumor cells in the vessels, the number of mitoses, including atypical ones. In addition, the cellular elements of different maturity (in \%): low differentiated (LD), moderately differentiated (MD), highly differentiated (HD) cells were determined in tumors. The degree of malignancy and histologic type of the tumor were evaluated according to the generally accepted criteria.

The content of free heparin fractions in plasma were determined by method proposed by Mykhailychenko B., Vydyborets S. (2000) [7].

The research materials were statistically processed according to the relevant programs. The significance of the difference was assessed using the Student's Difference Factor t-test $(p<0.05)$.

\section{- RESULTS AND DISCUSSION}

The data on the findings of studies of the plasma level of free heparin in the examined subjects are given in Table 1 . 
Table 1

The value of the plasma level of free heparin in the examined subjects $(M \pm m), \mu g / g$

\begin{tabular}{|l|l|l|l|l|}
\hline \multirow{2}{*}{ Value } & \multicolumn{2}{|l|}{ Groups of examined subjects } & \multicolumn{2}{l|}{$\begin{array}{l}\text { Significance } \\
\text { of differences (p) }\end{array}$} \\
\cline { 1 - 4 } & Control (n=50) & I (first), $\mathbf{n = 5 3}$ & II (second), $\mathbf{n = 3 9 2}$ & $\begin{array}{l}\mathrm{p}_{1}<0.05 \\
\mathbf{p}_{2}<0.05 \\
\mathbf{p}_{3}<0.05\end{array}$ \\
\hline Free heparin, $\mu \mathrm{g} / \mathrm{g}$ & $19.42 \pm 1.45$ & $20.59 \pm 2.14$ & $21.34 \pm 2.73$ & \\
\hline
\end{tabular}

Notes: $p_{1}$ - significance of differences in patients of Group I compared with the control group; $p_{2}-$ significance of differences in patients of Group II compared with the control group; $p_{3}$ - significance of differences in patients of Groups I and II.

It should be noted that the value of the plasma level of free heparin in men of the control group was $19.37 \pm 1.46 \mu \mathrm{g} / \mathrm{g}$, and in women $19.48 \pm 1.47 \mu \mathrm{g} / \mathrm{g}$, in male patients of Group I - 20.59 $\pm 2.14 \mu \mathrm{g} / \mathrm{g}$, and in women $-21.46 \pm 2.21 \mu \mathrm{g} / \mathrm{g}$, with average values in this group of examined subjects $-20.95 \pm 2.17 \mu \mathrm{g} / \mathrm{g}$. The value of the plasma level of free heparin in men of Group II was $21.34 \pm 2.73 \mu \mathrm{g} / \mathrm{g}$, and in women $-22.01 \pm 2.87 \mu \mathrm{g} / \mathrm{g}$, with average values in this group of examined subjects $-21.64 \pm 2.74 \mu \mathrm{g} / \mathrm{g}$.

As can be seen from the data presented in Table 1, the value of the plasma level of free heparin in examined patients of Groups I and II was significantly higher than in the control group $(p<0.5)$. It should be noted that this value was significantly the highest in patients of Group II, which may indicate heparin impaired synthesis and processes of its release and inactivation under conditions of tumour intoxication and anaemic hypoxia $(p<0.05)$.

It is quite natural that when we were analysing the data obtained, we considered it necessary to study how the value of the plasma level of free heparin of patients with malignant neoplasms of the colon with concomitant AMN changes depending on the severity of the anaemia syndrome. The data are presented in Table 2.

As can be seen from the data presented in Table 2, in patients with malignant neoplasms of the colon with concomitant $A M N$, the value of the plasma level of free heparin increased in proportion to the increase in the severity of anaemia. That is, the severity of life-threatening anaemia in AMN in patients with malignant neoplasms of the colon is accompanied by a significant increase in the plasma level of free heparin, which obviously represents the peculiarities of its metabolism during the tumour process under conditions of tumour intoxication, anaemic hypoxia and may indicate imbalance in the processes of its synthesis, release and inactivation.

HPN, a physiologically active substance, one of the most active indirect anticoagulants, was discovered in 1916. According to the chemical molecular structure, HPN is a highly sulfated mucopolysaccharide, a classic glycosaminoglycan, which does not have an established structure and consists of successive residues of L-D-glucuronic acid and 2-amino-2-deoxy-L-Dglucose. In HPN, several polysaccharide chains of different lengths and molecular weights are connected with one common protein core. The protein fragment of HPN molecule is unique because it consists only of serine and glycine residues [8]. A characteristic feature of HPN molecular structure is the disaccharide component, which is repeated and contains glucosamine and glucuronic acid. The different degrees of sulfatation and the peculiar- 
Table 2

The value of the plasma level of free heparin in patients with malignant neoplasms of the colon with concomitant AMN depending on the severity of the anaemia $(M \pm m), \mu g / g$

\begin{tabular}{|c|c|c|}
\hline \multicolumn{2}{|c|}{ Groups of examined subjects (n) } & \multirow[b]{2}{*}{ Significance of differences ( $p$ ) } \\
\hline Control $(n=50)$ & $\begin{array}{l}\text { Malignant neoplasms of the colon with } \\
\text { concomitant AMN }(n=57)\end{array}$ & \\
\hline \multirow{4}{*}{$19.42 \pm 1.45$} & $\begin{array}{l}\text { mild anaemia }(n=29) \\
19.48 \pm 1.49\end{array}$ & $\begin{array}{l}\mathrm{p}_{1}<0.05 \\
\mathrm{p}_{2}>0.05 \\
\mathrm{p}_{4}>0.05 \\
\mathrm{p}_{5}<0.05 \\
\mathrm{p}_{6}<0.001\end{array}$ \\
\hline & $\begin{array}{l}\text { moderate anaemia }(n=12) \\
21.62 \pm 2.25\end{array}$ & $\begin{array}{l}\mathrm{p}_{1}<0.05 \\
\mathrm{p}_{2}<0.05 \\
\mathrm{p}_{3}>0.05 \\
\mathrm{p}_{5}<0.05 \\
\mathrm{p}_{6}<0.01\end{array}$ \\
\hline & $\begin{array}{l}\text { severe anaemia }(n=10) \\
22.38 \pm 2.21\end{array}$ & $\begin{array}{l}\mathrm{p}_{1}<0.05 \\
\mathrm{p}_{2}<0.05 \\
\mathrm{p}_{3}<0.05 \\
\mathrm{p}_{4}<0.05 \\
\mathrm{p}_{6}<0.01\end{array}$ \\
\hline & $\begin{array}{l}\text { life-threatening anaemia }(n=6) \\
23.15 \pm 3.02\end{array}$ & $\begin{array}{l}\mathrm{p}_{1}<0.01 \\
\mathrm{p}_{2}<0.01 \\
\mathrm{p}_{3}<0.05 \\
\mathrm{p}_{4}<0.01 \\
\mathrm{p}_{5}<0.01\end{array}$ \\
\hline
\end{tabular}

Notes: $\mathrm{p}_{1}$ - significance of differences compared with the control group; $\mathrm{p}_{2}$ - significance of differences with patients of Group Il; $p_{3}$ - significance of differences with patients who had mild anaemia; $p_{4}$ - significance of differences with patients who had moderate anaemia; $p_{5}$ - significance of differences with patients who had severe anaemia; $p_{6}$ - significance of differences with patients who had life-threatening anaemia.

ities of the physicochemical parameters of the molecule determine the HPN heterogeneity. In tissues, HPN exists in the form of proteoglycan macromolecules with different molecular weights and is found in all mammals. As a result of enzymatic depolymerization, macromolecular HPN is converted into physiologically active forms.

The synthesis of HPN in the human body mainly occurs in the cytoplasm of mast cells, where it can be in a free state, or in the form of a complex heparin-zinc-histamine [9]. In the peripheral blood, the HPN depot contains neutrophilic leukocytes $[6,10]$. HPN is a part of the sulfated polysaccharides of tissues and its specific gravity is up to $5 \%$. In response to various stimuli, in particular, hypoxia, HPN is released from the depot granules. At the same time, eosinophil chemotactic factor, histamine, serotonin, dopamine, proteases (tryptases and chymases) and others are simultaneously released [8]. Mast cells are able not only to synthesize but also to absorb HPN from the blood circulation and to include it in the granules, as well as glycogen, inulin, dextrin, carboxymethyl cellulose [9]. Depending on the structural characteristics of the polysaccharide part of the HPN molecule, the manifestations of the relationship between the internal structures of labrocytes and polymers, which have penetrated to them, are different; with the help of unfractionat- 
ed 35S-heparin, it has been demonstrated that the HPN, which is accumulated by mast cells of the connective cell type with an enhanced coagulant potential of blood, is released from them into the blood circulation and involved in the reactions of hemostasis [8].

The release of HPN from mast cells occurs by endo- and exocytosis. Stress effects are accompanied with an enhancement of the former, since the granulolysis index in mast cells is rapidly growing by 3.3 times, while the degranulation index is only by $28 \%$. The enhancement of degranulation is manifested by an increase in the number of mast cells with moderate and strong degranulation by more than 2 times. It has been established that immobilization stress leads to a significant increase in the secretory activity of mast cells, and as a consequence, the index of saturation of mast cells with heparin decreases dramatically [9]. Mast cells which have poor HPN reserves in the cytoplasm due to its enhanced release under stress are able (with an excess of unfractionated HPN in the blood in a relatively short period) to restore its level.

As we have already noted, one of the factors which can initiate processes of degranulation of mast cells is hypoxia. Iron deficiency anaemia, accompanied by a syndrome of hypoxia and sideropenia, is accompanied by impaired metabolism of HPN due to depletion of compensatory-adaptive reactions to eliminate hypoxia. It is possible that the degranulation processes in mast cells directly depend on the degree of hypoxia of peripheral tissues, since a direct relationship between the level of hyperheparinemia and the severity of anaemia has been established [5, 6]. Obviously, such patterns are characteristic of the mechanisms of pathophysiological changes in AMN in CRC.

Inactivation of HPN takes place mainly in the liver, but $20 \%$ of it is excreted in urine. Degradation of the polysaccharide complexes of HPN is carried out by endoglycosides specific for this process, primarily by endoglucuronidase. Hyaluronate is deposited by cells and involved in cell adhesion processes [8]. There are two phases in the elimination of heparin - a rapid phase and a slower phase. There is an assumption that the rapid elimination of HPN is determined by its binding to the receptors of endothelial cells and macrophages. Partial depolymerization and desulfatation of HPN occurs in cells, after which molecule fragments are apparently released into the blood circulation and then excreted in urine by the kidneys. It is assumed that the phase of a slower clearance occurs provided that all cellular HPN receptors are saturated. This statement is supported by the fact that the half-life of HPN depends on the dose administered. So, at a dose of $100 \mathrm{U} / \mathrm{kg}$, the halflife was one hour; at low doses, its excretion decreases nonlinearly [9]. It is believed that HPN is able to bind to proteins which neutralise it. These include glycoprotein, platelet factor 4 , vitronectin, etc. The high plasma level of these proteins can cause relative resistance to heparin. HPN is not absorbed in the digestive tract.

The data on the plasma level of the free HPN fraction are eclectic. In our opinion, such contradictions could be due to the accuracy of the technique, equipment, quality of reagents or other factors.

In clinical practice, the quantitative determination of the HPN content is a significant problem, since indirect indicators based on the assessment of its biological effect are used in many cases. Existing methods for determining the HPN content require preliminary extraction, for example, with alkalis, 
followed by separation from impurities, and are not available for widespread use due to the lack of specific reagents and/or instruments. In particular, immunological determination of the HPN content requires appropriate anti-HPN antibodies, and spectrophotometric analysis requires chromogenic substrates. Methods for analysis of commercial HPN preparations, which cannot be used in clinical practice without preliminary isolation from biosubstrates, have been developed in sufficient detail.

Recently, considerable attention has been paid to electrophoresis in various gels, especially in polyacrylamide gels with high resolution. HPN is an acid and its macromolecule contains a significant content of sulfo groups, which ensures an extremely high negative charge and significant mobility of its molecule in an electric field. In view of the above, it is quite justified to recently use electrophoretic techniques for the isolation and quantitative determination of the HPN content in biological substrates. The known electrophoretic techniques require preliminary purification of HPN isolated from biosubstrates and removal of interfering compounds, for example, nucleic acids. While performing the electrophoretic procedure, not only HPN is simultaneously isolated, but also other mucopolysaccharides, the identification of which is based on determining the level of electrophoretic migration and comparing the latter to standards $[7,8]$.

\section{- CONCLUSIONS}

1. In patients with IDA and colorectal cancer, which is accompanied by anaemia of malignant neoplasm, there are disorders in the exchange of free heparin, which is manifested by a significant increase in its plasma level. Involvement of HPN in numerous body's vital activities allows us to consider it as a compound with pronounced regulatory properties of not only peripheral but also central action.

2. Since at the stage of establishing the diagnosis there is an initial increase in the plasma level of free heparin in anaemia in malignant neoplasm caused by colorectal cancer, a promising direction of scientific and clinical research is to study the dynamic level of this biologically active compound in the course of treatment to use the value of its level as an additional criterion for assessing the degree of compensation of metabolic processes in the treatment of patients.

3. The value of the plasma level of free heparin in patients with anaemia in malignant neoplasm in colorectal cancer is significantly higher than in patients with iron deficiency anaemia; therefore, obviously, it can be used as an additional differential diagnostic criterion for differentiating these diseases.

\section{- REFERENCES}

1. Available at: http://www.esmo.org

2. Fedorenko Z.P., Kolesnik O.O., Gulak I.O., Ryzhov A.Yu., Sumkina O.V. (2019) Kolorektalnyi rak v Ukraini: epidemiologichni ta organizatsijni aspekty problemy [Colorectal cancer in Ukraine: the epidemiological and organizational aspects of the problem]. Prakticna onkologia. Practical oncology, no 2, pp. 9-16. DOI: 10.22141/2663-3272.2.2.2019.176026. (in Ukrainian).

3. World Cancer Research Fund International. Available at: http://www.wcrf.org 
4. Linchevskii O.V., Kovaliov O.O., Kolesnyk O.O., Beznosenko A.P. (2019) Zlojakisni novoutvorennja v Ukraini (analityko-statystychnyi dovidnyk) [Malignant neoplasms in Ukraine (analytical and statistical reference book)]. Praktycna onkologia. Practical Oncology, no 2(2), pp. 59-118. DOI: 10.22141/2663-3272.2.2.2019.176034 (in Ukrainian).

5. Andriiaka A. (2018) Anemiia zlokachestvennogo obrazovaniia: osobennosti vedenija pazientov [Anemia of malignant neoplasm: features of patient management]. Hematologija. Transfusiologija. Vostochnaja Evropa. vol. 4, no 2, pp. 223-229.

6. Greer J.P., Arber D.A., Glader B. (eds.) (2014) Wintrobe's clinical hematology. Philadelphia: Lippincott Williams \& Wilkins. 2278 p.

7. Mykhailychenko B., Vydyborets S. (2000) Metod kil'kisnogo vyznatshennia geparynu v biosubstratah [Method of quantitative determination of heparin in biosubstrates]. Laboratorna diagnostika, no 4, pp. 53-56.

8. Luniova G.G. (eds.) (2013) Klinichna biochimiia [Clinical Biochemistry]: Handbook. Kyiv: Atika, 1156 p. (in Ukrainian)

9. Bublij Yu. (2013) Heparyn: fiziologitchna rol' i klinitchne znatchennia porushen vmistu [Heparin: physiological role and clinical significance of disorders of content]. Ukrajinskij zhurnal gematologii i transfusiologii, no 6(17), pp. 5-10.

10. Korzh A. (2016) Soderzhanije svobodnogo geparina v plasma krovi, poluchenoi razlichnymi metodamy [Content of free heparin in the blood plasma obtained with different methods]. Hematologija. Transfusiologija. Vostochnaja Evropa, vol. 2, no 4, pp. 418-425.

Submitted/Подана: 17.05.2021

Accepted/Принята:23.05.2021

Contacts/Контакты: aandriiaka0806@gmail.com 